\title{
Immunopathologic Studies of Systemic Lupus Erythema- tosus. II. Antinuclear Reaction of $\gamma$-Globulin Eluted from Homogenates and Isolated Glomeruli of Kidneys from Patients with Lupus Nephritis *
}

\author{
Chandrasekharan Krishnan and Melvin H. Kaplan $\dagger$ \\ (From the Department of Medicine, Western Reserve University School of Medicine and \\ Metropolitan General Hospital, Cleveland, Ohio)
}

\begin{abstract}
Summary. The $\gamma \mathrm{G}$-globulin eluted at acid $\mathrm{pH}$ from kidney cortex homogenates and isolated glomeruli of five of six patients with lupus nephritis was found to exhibit antinuclear activity, which was not dependent on presence of fresh human serum. Specificity, as demonstrated by absorption of antinuclear activity, was related to nucleoprotein in three glomerular acid eluates and to DNA in two acid eluates as well as in a deoxyribonuclease digest of disrupted glomeruli in one patient. Antinuclear activity was not found in acid eluates of kidneys from two patients with chronic liver disease and chronic discoid lupus, respectively, and one with lupus nephritis. These patients had a low titer of serum antinuclear factor and lesser amounts of kidney bound immunoglobulins. The presence of antinuclear activity in eluates of kidneys appeared to correlate with the amount of glomerular bound immunoglobulin and the level of antinuclear antibodies in serum. These findings suggest that in lupus nephritis, part of the glomerular bound immunoglobulin is derived from serum antinuclear factors possibly deposited as immune complexes.
\end{abstract}

\section{Introduction}

The definition of immunoglobulin deposits in lupus kidneys has been approached by techniques applicable to dissociation of antigen-antibody complexes. Sections of lupus nephritis kidneys washed at acid $\mathrm{pH}$ (3.0 to 3.2) were found to lose considerable staining for $\gamma$-globulin in glomerular and vas-

\footnotetext{
* Submitted for publication February 21, 1966; accepted December 22, 1966.

This work was presented in part at the meeting of the American Association of Immunologists, Atlantic City, N. J., April 11-16, 1966 (1).

This work was supported by research grant HE-03726 from the National Heart Institute, U. S. Public Health Service, and by a grant from the Kidney Foundation of Northeast Ohio.

$\dagger$ Research Career awardee of the U. S. Public Health Service (5-K6-HE-4576). Address requests for reprints to Dr. M. H. Kaplan, Dept. of Medicine, Metropolitan General Hospital, Cleveland, Ohio.
}

cular sites as would be consistent with elution of antibody, whereas deposits of $\gamma$-globulin in tubular casts of presumed nonimmune origin were found to be little affected by this treatment $(2,3)$. Freedman and Markowitz (4) extended their observations to acid elution of globulin from isolated glomeruli obtained from the kidney of a patient with lupus nephritis. The eluted globulin was reported to react with cell nuclei in the presence of fresh human serum.

In further support of the relation of antinuclear factors to renal bound immunoglobulins, a preceding paper (5) reported a correspondence between the specific immunoglobulins deposited in renal glomeruli and in blood vessels and the immunoglobulin composition of circulating antinuclear factors. In the present study, the postmortem kidneys of six patients with systemic lupus erythematosus (SLE), and six control patients 
TABLE I

Summary of clinical and pathologic data*

\begin{tabular}{|c|c|c|}
\hline Patient & Renal involvement and duration & Renal pathology \\
\hline $\begin{array}{l}\text { 4, J.T. . 10-year-old Negro male } \\
\text { with SLE }\end{array}$ & $\begin{array}{l}\text { Proteinuria, RBC, leukocytes, } \\
\text { and casts in sediment for } 1 \text { year. }\end{array}$ & Proliferative and membranous glomerulitis \\
\hline $\begin{array}{l}\text { 5, E.S., 52-year-old Negro female } \\
\text { with SLE }\end{array}$ & $\begin{array}{l}\text { RBC, leukocytes in sediment, } \\
\text { severe proteinuria, and pro- } \\
\text { gressive azotemia for } 2 \text { months. }\end{array}$ & $\begin{array}{l}\text { Membranous glomerulitis with "wire loops" } \\
\text { and focal fibrinoid necrosis }\end{array}$ \\
\hline 6, M.G., 23-year-old Negro female & $\begin{array}{l}\text { Proteinuria and RBC, and leuko- } \\
\text { cytes in sediment for } 7 \text { years; } \\
\text { progressive azotemia for } 1 \text { year. }\end{array}$ & $\begin{array}{l}\text { Advanced hyalinization and sclerosis of } \\
\text { most glomeruli; occasional wire loops; } \\
\text { focal endothelial proliferation }\end{array}$ \\
\hline $\begin{array}{l}\text { 8, E.L., 54-year-old Negro female } \\
\text { with gram-negative bacteremia, } \\
\text { chronic discoid lupus, pyelonephritis }\end{array}$ & Pyuria for 4 years. & Pyelonephritis; minimal glomerular change \\
\hline $\begin{array}{l}\text { 9, E.N., } 61 \text {-year-old white male with } \\
\text { hypertensive and arteriosclerotic } \\
\text { heart disease }\end{array}$ & None & Mild nephrosclerosis \\
\hline $\begin{array}{l}\text { 10, T.K., 70-year-old white male } \\
\text { with arteriosclerotic heart disease, } \\
\text { myocardial infarction }\end{array}$ & None & Mild nephrosclerosis \\
\hline $11 \dagger$ & & Normal \\
\hline $\begin{array}{l}\text { 12, H.E., } 61 \text {-year-old white male } \\
\text { with arteriosclerotic heart disease, } \\
\text { myocardial infarction }\end{array}$ & None & Normal \\
\hline
\end{tabular}

* Abbreviations: SLE = systemic lupus erythematosus; RBC = erythrocytes.

$\dagger$ Normal postmortem kidney; clinical data unknown.

were subjected to acid elution. The immunoglobulins eluted from both renal cortex homogenates and isolated glomeruli of lupus kidneys were found to exhibit antinuclear activity, which included serologic specificities for nucleoprotein and DNA.

\section{Methods}

Kidneys for elution. Kidneys were made available within 12 hours of death and stored frozen at $-20^{\circ} \mathrm{C}$. The kidneys were obtained from six patients with lupus nephritis (1 to 6); one with chronic liver disease and positive LE cell test (7); one with chronic discoid lupus, pyelonephritis, and positive antinuclear factor (8); and four control patients who died of varying causes other than renal disease ( 9 to 12 ). The clinical histories and postmortem findings in Patients 1 (FP), 2 (DR), 3 (CC), and 7 (BV) were described in a preceding paper (5). Pertinent data on the remaining eight patients are summarized in Table I.

Preparation of eluates from kidney cortex homogenates. Segments of frozen kidney were allowed to thaw, and approximately 5- to $10-\mathrm{g}$ portions of cortex were removed. The tissue was minced in isotonic saline and washed twice by decantation to remove gross blood and clots. The mince was suspended in 5 vol of saline and homogenized in a Potter-Elvehjem grinder in an ice bath until a smooth suspension was obtained. The suspen- sion was centrifuged in the cold at $3,000 \mathrm{rpm}(2,000 \mathrm{~g})$ for 15 minutes and the supernates were saved. The packed tissue was then resuspended in $10 \mathrm{vol}$ of saline and agitated gently on a mechanical shaker for 15 minutes at room temperature. The mixture was centrifuged for 15 minutes at $2,000 \mathrm{~g}$, and the tissue sediment was resuspended in 10 vol of saline and washed again. This washing procedure was repeated six times. All supernatant washes were saved.

The washed tissue sediment was suspended in 4 vol of saline and then divided into two aliquots. One, taken as the control, was adjusted to $\mathrm{pH}$ 7.0. The other was adjusted to $\mathrm{pH} 3.0$ with $0.1 \mathrm{~N} \mathrm{HCl}$. The two suspensions were transferred to graduated tubes, and the volume of each was made up with saline to five times that of the packed tissue. The tubes were gently agitated on a mechanical shaker at room temperature for 2 hours. After centrifugation at $2,000 \mathrm{~g}$, the supernates were transferred to graduated tubes. One drop phenol red indicator $(0.2 \%)$ and $0.1 \mathrm{ml} 0.3 \mathrm{M} \mathrm{Na}_{2} \mathrm{HPO}_{4}$ were added to each supernate, and the mixture was made neutral with $0.1 \mathrm{~N} \mathrm{NaOH}$. A scanty flocculation that occasionally developed after standing in the cold was removed by centrifugation. The washes were centrifuged at 8,000 $\mathrm{rpm}(7,500 \mathrm{~g})$ for 30 minutes. Protein content of eluates and washes was determined by a modified FolinCiocalteu procedure (6) calibrated by micro-Kjeldahl technique with rabbit $\gamma$-globulin as reference standard.

The eluates and washes were dialyzed against a $1: 10$ dilution of buffered saline $(0.01 \mathrm{M}$ phosphate, $\mathrm{pH}$ 7.2) 
for 48 hours in the cold and were freeze-dried. The lyophilized samples were dissolved in sufficient distilled water to give a protein concentration of 1 to $2 \mathrm{mg}$ protein $\mathrm{N}$ per $\mathrm{ml}$. Each sample was rendered isotonic by dialysis against buffered saline. Finally, merthiolate was added at a concentration of $1: 10,000$ as preservative.

Isolation of glomeruli and elution. Glomeruli were isolated from one whole kidney by the procedure of Greenspon and Krakower (7) from each of the following: Patients 1 to 6 with lupus nephritis, Patient 7 with chronic liver disease, and Patients 11 and 12 , who were normal controls. All steps for the separation of glomeruli were carried out in the cold. The glomerular suspensions of more than $90 \%$ purity were packed by centrifuging at $2,000 \mathrm{~g}$. We washed the glomerular sediment six times in 10 vol of saline to remove all unbound protein. Equal portions of glomeruli were eluted at $\mathrm{pH}$ 3.0 and $\mathrm{pH} 7.0$ in isotonic saline for 2 hours at room temperature with gentle agitation. The eluates were neutralized and concentrated by freeze-drying, dissolved in distilled water, and rendered isotonic. The final solutions of eluates and washes contained 0.1 to $0.2 \mathrm{mg}$ protein $\mathrm{N}$ per $\mathrm{ml}$.

By the above method the total protein yield was low, even in acid eluates. The isolated whole glomeruli retained a considerable amount of $\gamma \mathrm{G}$-globulin that could not be eluted. The technique was, therefore, modified in later experiments with kidneys of four lupus patients $(1,4$ to 6$)$ and one control kidney (Patient 12). After isolation, the glomeruli were disrupted in a PotterElvehjem grinder until not more than $10 \%$ of them were intact. Washing was done as before. To release antibodies to DNA and to destroy nucleoproteins and DNA, we subjected the glomerular preparation to deoxyribonuclease treatment. DNA-ase I (once recrystallized) ${ }^{1}$ was used at a concentration of $0.25 \mathrm{mg}$ per $\mathrm{ml}$ in $0.1 \mathrm{M}$ $\mathrm{KH}_{2} \mathrm{PO}_{4}$, pH 7.0, containing $2.5 \mu \mathrm{M} \mathrm{MgCl}$ per ml. Ten vol of the enzyme solution was added to 1 vol of homogenized glomeruli and incubated at $37^{\circ} \mathrm{C}$ for $60 \mathrm{~min}$ utes. The mixture was then dialyzed overnight in the cold against $0.1 \mathrm{M} \mathrm{KH} \mathrm{KHO}_{4}, \mathrm{pH} 7.0$, containing $2.5 \mu \mathrm{M}$ $\mathrm{MgCl}_{2}$ per $\mathrm{ml}$. After this, it was dialyzed briefly against $0.05 \mathrm{M}$ phosphate-citrate-buffered saline. The tissue was then separated from the supernate, washed twice, and subjected to acid elution at pH 3.0 as described above. The supernate obtained after enzymatic treatment and the acid eluate were both fractionated by $50 \%$ ammonium sulfate precipitation, and the globulin fractions were tested for antibodies to nuclear antigens.

Immunoelectrophoretic analysis of eluates and washes. The electrophoretic procedure was performed by the Scheidegger technique (8) with an Agafor cell. Precipitation lines were allowed to develop for 2 to 3 days, and the slides were than washed and stained with amido black 10B. The antisera employed included antiserum to whole human serum, rabbit anti- $\gamma \mathrm{G}$-globulin, goat anti$\gamma \mathrm{A}-$ globulin, goat anti- $\gamma \mathrm{M}-$ globulin, and rabbit anti- $\beta_{1 \mathrm{c}} /$ $\beta_{1 \Delta}$-globulin. The anti-immunoglobulin sera were sup-

1 Worthington Biochemical Corp., Freehold, N. J. plied commercially. ${ }^{2}$ The anti- $\beta_{1 \mathrm{c}}-$ globulin serum was donated. ${ }^{3}$

Immunofuorescent staining of immunoglobulins and complement $\beta_{1 c}$-globulin in kidney sections. The frozen tissues were sectioned in a cryostat at $4 \mu$ and were washed for 20 minutes in two changes of buffered saline (0.01 M phosphate, $\mathrm{pH}$ 7.2) before immunofluorescent staining. The fluorescent conjugates specific for $\gamma$-globulin and for $\gamma \mathrm{M}-, \gamma \mathrm{G}-$, and $\gamma \mathrm{A}$-globulins have been described previously (5). The rabbit anti- $\boldsymbol{\beta}_{1 \mathbf{c}}-$ globulin antiserum was employed in an indirect immunofluorescent procedure with goat antirabbit globulin conjugate. The conjugates were absorbed with acetone-dried mouse organ powder to remove nonspecific reactivity. The fluorescent microscope was a Zeiss unit equipped with an Osram HBO-200 mercury lamp.

Acid washing of kidney sections. The effect of acid washing on immunofluorescent staining of the $\gamma \mathrm{G}$-globulin deposits was tested as follows. Sections of each kidney were washed for 2 hours with constant shaking at room temperature in Coplin jars in each of the following solutions: 1) $0.01 \mathrm{M}$ phosphate-buffered saline, $\mathrm{pH}$ 7.2 ; 2) $0.05 \mathrm{M}$ citrate-buffered saline, $\mathrm{pH} 3.2$; and 3) isotonic saline adjusted with $0.1 \mathrm{~N} \mathrm{HCl}$ to $\mathrm{pH} 3.0$. The $\mathrm{pH}$ of the washing solutions remained unchanged at the end of the washing period. All sections were further washed for 10 minutes in two changes of phosphatebuffered saline, $\mathrm{pH}$ 7.2. They were then stained with a rabbit antihuman $\gamma \mathrm{G}$-globulin conjugate for 1 hour at room temperature.

Detection of antinuclear activity of eluates and washes by immunofluorescence. We applied an indirect immunofluorescent technique using sections of normal human liver and kidney and normal mouse and rabbit kidney and buffy coat smears from heparinized human blood (9). The leukocyte smears were exposed to cold acetone for 10 minutes, whereas the tissue sections were stained without prior fixation.

The sections or smears were overlaid with 1 or 2 drops of the test material and allowed to stand in a moist chamber for 1 hour at room temperature and overnight in the cold. The slides were then washed three times in buffered saline for 10 minutes, and the specific antihuman immunoglobulin conjugates were applied for 1 hour at room temperature. After washing in three changes of buffered saline, the slides were mounted in $10 \%$ buffered glycerol. The fluorescent conjugates employed were antisera to human $\gamma \mathrm{G}-, \gamma \mathrm{A}-$, and $\gamma \mathrm{M}$-globulins.

Absorption with DNA and nucleoprotein. Highly polymerized calf thymus DNA ${ }^{1}$ was used at a concentration of $2 \mathrm{mg}$ per $\mathrm{ml}$ saline. Nucleoprotein was prepared from calf thymus at low ionic strength according to the method of Chargaff (10). The absorption techniques were the same as those employed in this laboratory previously (9).

DNA-coated bentonite flocculation. The technique of

\footnotetext{
2 Immunology, Inc., Glen Ellyn, Ill., and Mann Research Labs., New York, N. Y.

${ }^{3}$ Dr. Hans Müller-Eberhard.
} 
TABLE II

Glomerular bound immunoglobulins and serologic data

\begin{tabular}{|c|c|c|c|c|c|c|c|}
\hline \multirow[b]{3}{*}{ Patient } & \multirow{2}{*}{\multicolumn{4}{|c|}{$\begin{array}{l}\text { Bound immunoglobulins and complement } \\
\beta_{1 \mathrm{C}} \text { in glomeruli }\end{array}$}} & \multicolumn{3}{|c|}{ Serological tests } \\
\hline & & & & & \multirow{2}{*}{$\begin{array}{c}\gamma \mathrm{G}-\text { globulin anti- } \\
\text { nuclear factor titer } \\
\text { range* }\end{array}$} & \multirow{2}{*}{$\begin{array}{c}\text { Anti-DNA } \\
\text { titer }\end{array}$} & \multirow{2}{*}{$\begin{array}{c}\text { LE cell } \\
\text { test }\end{array}$} \\
\hline & $\gamma \mathrm{G}$ & $\gamma \mathbf{M}$ & $\gamma \mathrm{A}$ & $\boldsymbol{\beta}_{1 \mathrm{C}}$ & & & \\
\hline 1. F.P. (lupus nephritis) & $4+$ & $1+$ & $1+$ & $3+$ & $1 / 32-1 / 64$ & 0 & + \\
\hline 2. D.R. (lupus nephritis) & $4+$ & 0 & $1+$ & $3+$ & $1 / 64-1 / 256(8)$ & $1 / 64$ & + \\
\hline 3. C.C. (lupus nephritis) & $4+$ & 0 & 0 & $4+$ & $1 / 64$ (2) & $1 / 8$ & + \\
\hline 4. J.T. (lupus nephritis) & $4+$ & 0 & 0 & $3+$ & $1 / 128-1 / 512(3)$ & 0 & 0 \\
\hline 5. E.S. (lupus nephritis) & $4+$ & 0 & 0 & $3+$ & $1 / 64 \quad(1)$ & $1 / 64$ & + \\
\hline 6. M.G. (lupus nephritis) & $1+$ & 0 & 0 & \pm & $1 / 16$ (1) & 0 & + \\
\hline 7. B.V. (chronic liver disease) & $2+$ & $1+$ & 0 & $2+$ & $1 / 1 \quad(2)$ & 0 & + \\
\hline $\begin{array}{l}\text { 8. E.L. (chronic discoid lupus } \\
\text { and pyelonephritis) }\end{array}$ & $1+$ & 0 & 0 & 0 & $1 / 2-1 / 16 \quad(6)$ & 0 & 0 \\
\hline 9. Control & 0 & 0 & 0 & 0 & & & \\
\hline 10. Control & Trace & 0 & 0 & 0 & & & \\
\hline 11. Control & Trace & 0 & 0 & 0 & & & \\
\hline 12. Control & Trace & 0 & 0 & 0 & & & \\
\hline
\end{tabular}

* Range of titers found with sera collected at varying intervals. Number in parentheses is the number of different sera tested.

Bozicevich, Nasou, and Kayhoe (11) was followed without addition of methylene blue.

Deoxyribonuclease treatment of tissue sections. DNAase solution at the same concentration as used for treating homogenized glomeruli was employed. The enzyme solution was applied to the tissue section at $37^{\circ} \mathrm{C}$ for 60 minutes, and the sections were washed twice for $5 \mathrm{~min}$ utes with buffered saline and then reacted with test eluates, as described above.

\section{Results}

Immunofluorescent staining of kidneys for bound immunoglobulins. The results observed with kidney sections of three patients with lupus nephritis (1 to 3 ) and the patient with chronic liver disease ( 7 ) have been described in detail in the preceding paper (5). The findings on these and the other eight kidneys used in this study are summarized in Table II. Five of the six patients with lupus nephritis showed extensive deposits of $\gamma \mathrm{G}-$ and $\beta_{\mathbf{1 C}}$-globulins. Scattered renal tubular nuclei in kidneys of Patients 1 and 2 showed bound $\gamma \mathrm{G}$-globulin but no $\beta_{1 \mathrm{C}}$-globulin, as illustrated in Figure 1. Patient 6 (MG) with lesser deposits of $\gamma \mathrm{G}$ - and $\beta_{1 \mathrm{c}}$-globulins had advanced renal disease with "end stage" kidneys characterized by much glomerular sclerosis and hyalinization. This patient also had a low titer of serum antinuclear antibodies.

Result of acid washing of kidney sections. Sections of kidneys from Patients 1 and 2 showed marked diminution of staining for $\gamma \mathrm{G}$-globulin in glomeruli after washing at acid $\mathrm{pH}$, whereas after washing at $\mathrm{pH} 7.2$, bright glomerular staining persisted. Staining of tubular casts was unaffected by the acid washes, but tubular cell nuclear staining, as previously described (5), was completely abolished. With Patient 3, only slight reduction of $\gamma$ G-globulin staining of glomeruli was noted after the acid washes. Staining of tubular casts and blood vessel walls was also little affected. The kidney sections of Patient 7 with chronic liver disease showed marked reduction of $\gamma$ G-globulin staining in glomeruli after acid washes. With Patient 8 with discoid lupus, some reduction of glomerular bound $\gamma$ G-globulin was also noted. The three control kidneys of Patients 9 to 11 , which showed only minimal or absent staining, demonstrated similar reactions after neutral or acid washes.

Immunoglobulin content and antinuclear activity of washes and eluates of kidney cortex homogenates. With the six successive saline washes, the number of serum proteins detected in the washings by immunoelectrophoresis gradually diminished. $\gamma$ G-Globulin was absent or detectable only in trace amounts in the sixth wash. Antinuclear activity attributable to contaminating serum antinuclear factor could not be demonstrated after the fourth wash in Patient 1 , the second in Patient 2, or in any wash of the remaining six patients.

The acid eluates from three lupus kidneys, tested at a concentration of 0.6 to $2.0 \mathrm{mg}$ protein $\mathrm{N}$ per $\mathrm{ml}$, showed antinuclear activity. Anti- 


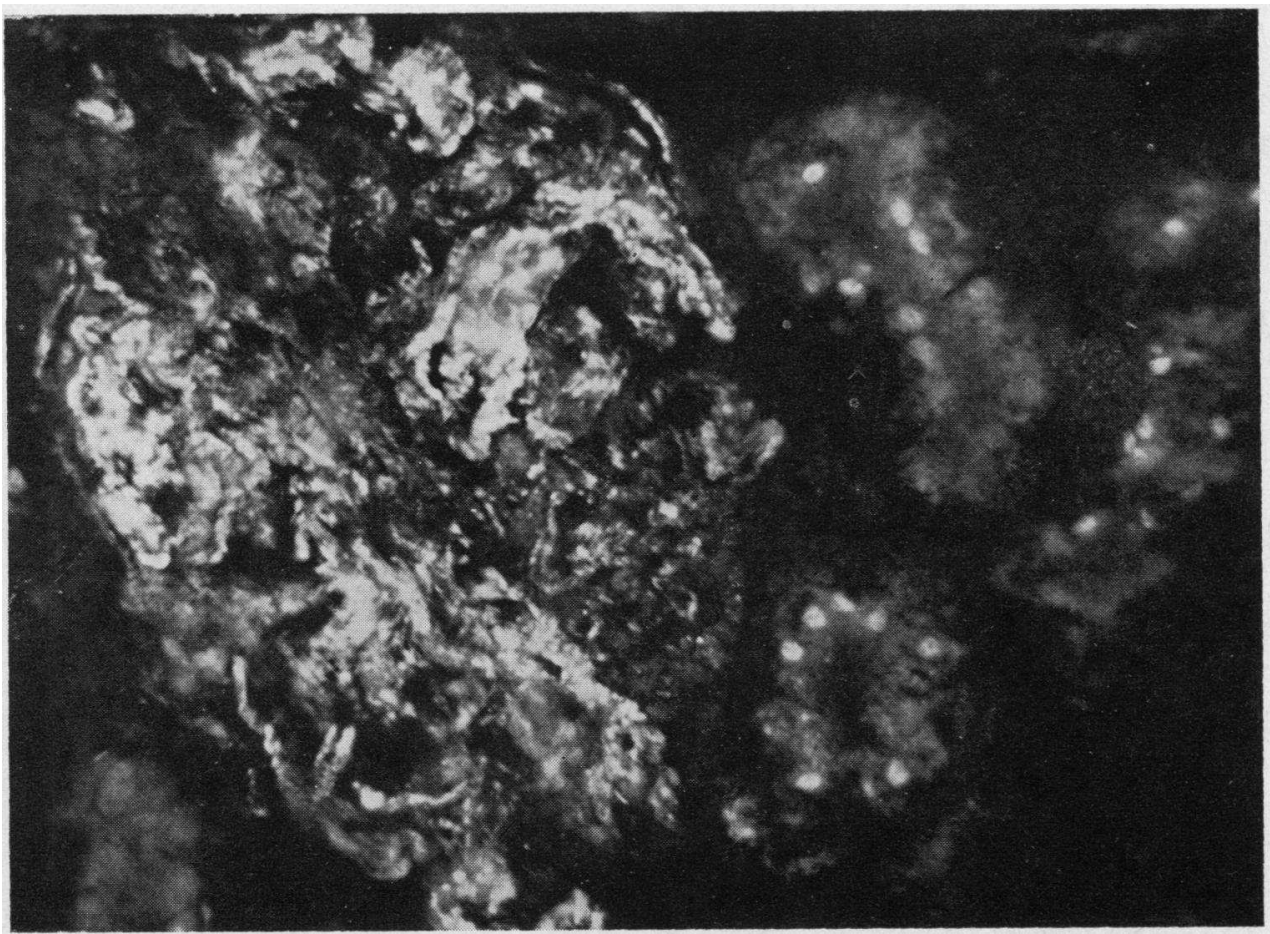

Fig. 1. Bound $\gamma$ G-GLOBUlin distributed in GLOMERUlar CAPILlary LOOPS AND IN SCATtERED tUbular NUClei [Patient 2 (DR)]. ( ( 312.$)$

nuclear reactions were demonstrable with anti$\gamma$ G-globulin conjugate but not with anti- $\gamma \mathrm{M}$ - or anti- $\gamma \mathrm{A}$-globulin conjugates. In contrast, the $\mathrm{pH}$ 7.0 saline eluates of all three kidneys failed to exhibit antinuclear reaction. Acid and neutral eluates from kidney cortex homogenates of the remaining five patients were nonreactive (Table III). The nuclear staining given by acid eluates was of weak or moderate intensity after the usual 1-hour staining reaction but considerably enhanced after overnight incubation in the cold. Fresh normal human serum was not required for demonstration of nuclear reaction, and its addition to the eluates produced no detectable change in staining intensity. Furthermore, eluates that were nonreactive, as in Patients 7 to 11 , remained nonreactive in the presence of fresh human serum.

The nuclear staining with liver and kidney sections was of a homogeneous and occasionally speckled pattern. Acid eluates showed no reactivity by immunofluorescence with non-nuclear components of normal human, rabbit, and mouse kidney sections, including cell cytoplasm, renal basement membranes, or vessel walls.
TABLE III

Elution of homogenates of kidney cortex

\begin{tabular}{|c|c|c|c|c|}
\hline Patient & Eluate & $\begin{array}{l}\text { Concen- } \\
\text { tration } \\
\text { of test } \\
\text { eluate }\end{array}$ & $\begin{array}{l}\text { Presence } \\
\text { of } \gamma \mathrm{G}- \\
\text { globulin }\end{array}$ & $\begin{array}{l}\text { Antinu- } \\
\text { clear } \\
\text { activity }\end{array}$ \\
\hline & \multicolumn{4}{|c|}{$m g N / m l$} \\
\hline 1. F.P. & $\begin{array}{ll}\text { Saline, } & \text { pH } \\
\text { Acid, } & \text { pH } \mathbf{3 . 0}\end{array}$ & $\begin{array}{l}2.0 \\
2.0\end{array}$ & + & $\begin{array}{c}0 \\
++\end{array}$ \\
\hline 2. D.R. & $\begin{array}{ll}\text { Saline, pH } & 7.0 \\
\text { Acid, } & \text { pH } \mathbf{3 . 0}\end{array}$ & $\begin{array}{l}1.0 \\
1.0\end{array}$ & $\begin{array}{c}\text { Trace } \\
++\end{array}$ & $\begin{array}{l}0 \\
++\end{array}$ \\
\hline 3. C.C. & $\begin{array}{l}\text { Saline, pH } 7.0 \\
\text { Acid, pH } 3.0\end{array}$ & $\begin{array}{l}0.6 \\
0.6\end{array}$ & + & $\stackrel{0}{++}$ \\
\hline 7. B.V. & $\begin{array}{l}\text { Saline, pH } 7.0 \\
\text { Acid, pH } \mathbf{3 . 0}\end{array}$ & $\begin{array}{l}2.0 \\
2.0\end{array}$ & $\begin{array}{l}\text { Trace } \\
\text { Trace }\end{array}$ & $\begin{array}{l}\mathbf{0} \\
\mathbf{0}\end{array}$ \\
\hline 8. E.L. & $\begin{array}{l}\text { Saline, pH } 7.0 \\
\text { Acid, }\end{array}$ & $\begin{array}{l}2.3 \\
2.0\end{array}$ & ++ & $\begin{array}{l}\mathbf{0} \\
\mathbf{0}\end{array}$ \\
\hline 9. Control & $\begin{array}{ll}\text { Saline, } & \text { pH } \\
\text { Acid, } & \text { pH } \mathbf{3 . 0}\end{array}$ & $\begin{array}{l}1.2 \\
1.5\end{array}$ & + & $\begin{array}{l}\mathbf{0} \\
\mathbf{0}\end{array}$ \\
\hline 10. Control & $\begin{array}{l}\text { Saline, pH } 7.0 \\
\text { Acid, pH } \mathbf{3 . 0}\end{array}$ & $\begin{array}{l}1.3 \\
1.2\end{array}$ & $\begin{array}{l}\text { Trace } \\
+\end{array}$ & $\begin{array}{l}\mathbf{0} \\
\mathbf{0}\end{array}$ \\
\hline 11. Control & $\begin{array}{ll}\text { Saline, } & \text { pH } \\
\text { Acid, } & \text { pH } \mathbf{3 . 0}\end{array}$ & $\begin{array}{l}1.3 \\
1.4\end{array}$ & $\begin{array}{c}\text { Trace } \\
+\end{array}$ & $\begin{array}{l}\mathbf{0} \\
\mathbf{0}\end{array}$ \\
\hline
\end{tabular}

The acid eluate from the kidney homogenate of Patient 1 was available in sufficient quantity to perform absorption tests with calf thymus nucleoprotein and DNA. Absorption with nucleoprotein resulted in complete abolition of nuclear reactivity, whereas on absorption with DNA only partial 
TABLE IV

Eluates of isolated whole glomeruli

\begin{tabular}{|c|c|c|c|c|c|}
\hline Patient & Eluate & $\begin{array}{l}\text { Packed } \\
\text { volume of } \\
\text { glomeruli }\end{array}$ & $\begin{array}{l}\text { Concen- } \\
\text { tration } \\
\text { of test } \\
\text { eluate }\end{array}$ & $\begin{array}{l}\text { Presence of } \\
\gamma \mathrm{G} \text {-globulin }\end{array}$ & $\begin{array}{l}\text { Antinu- } \\
\text { clear } \\
\text { activity }\end{array}$ \\
\hline 2. D.R. (lupus nephritis) & $\begin{array}{lll}\text { Saline, } & \text { pH } & 7.0 \\
\text { Acid, } & \text { pH } & 3.0\end{array}$ & $\begin{array}{l}0.3 \\
0.3\end{array}$ & $\begin{array}{l}0.1 \\
0.1\end{array}$ & $\begin{array}{l}0 \\
+\end{array}$ & $\begin{array}{l}0 \\
+\end{array}$ \\
\hline 3. C.C. (lupus nephritis) & Acid, pH 3.0 & 0.4 & 0.2 & ++ & + \\
\hline 7. B.V. (chronic liver disease) & $\begin{array}{lll}\text { Saline, } & \text { pH } & 7.0 \\
\text { Acid, } & \text { pH } & 3.0\end{array}$ & $\begin{array}{l}0.4 \\
0.4\end{array}$ & $\begin{array}{l}0.2 \\
0.2\end{array}$ & $\begin{array}{c}\text { Trace } \\
+\end{array}$ & $\begin{array}{l}0 \\
0\end{array}$ \\
\hline 8. Control & Acid, $\quad$ pH 3.0 & 0.5 & 0.2 & 0 & 0 \\
\hline
\end{tabular}

loss of staining occurred. After treatment with DNA-ase, nuclei of human liver sections were found to be no longer reactive with eluate.

On immunoelectrophoretic analysis, the $\mathrm{pH} 7.0$ eluates showed traces of $\gamma \mathrm{G}$-globulin and albumin despite the previous six washes. Acid eluates in general showed stronger precipitin arcs for $\gamma \mathrm{G}$ globulin than observed with neutral eluates, particularly in Patients 2 and 8 . We could not detect $\gamma \mathrm{M}$ - and $\beta_{1 \mathrm{C}}$-globulin in any of the acid or saline eluates. $\gamma \mathrm{A}$-Globulin was found in both saline and acid eluates of Patient 1 only. $\gamma \mathrm{A}$-Globulin antinuclear activity could not be demonstrated with either of these eluates.

Washes and eluates of isolated glomeruli. The protein content of washes of isolated glomeruli was much less than in washes of cortex homogenates. At the test concentration of 0.1 to 0.2 $\mathrm{mg}$ protein $\mathrm{N}$ per $\mathrm{ml}, \gamma \mathrm{G}$-globulin was not detected in any patient after the second wash, nor was any serum protein detected in the fifth and sixth washes. None of the washes exhibited antinuclear activity.

Acid elution of isolated whole glomeruli gave a relatively low yield of 0.02 to $0.08 \mathrm{mg}$ protein $\mathrm{N}$. Eluates were tested for antinuclear activity at a concentration of 0.1 to $0.2 \mathrm{mg}$ protein $\mathrm{N}$ per $\mathrm{ml}$ (Table IV). The acid eluates of glomeruli from three SLE patients (1 to 3 ) were reactive, whereas the acid eluates of Patients 7 and 11 were nonreactive. Neutral saline eluates showed negative reactions. The staining of reactive eluates was graded in intensity from weak to moderate after overnight reaction with tissue sections. Addition of fresh normal human serum had no effect on serologic activity of either reactive or non-

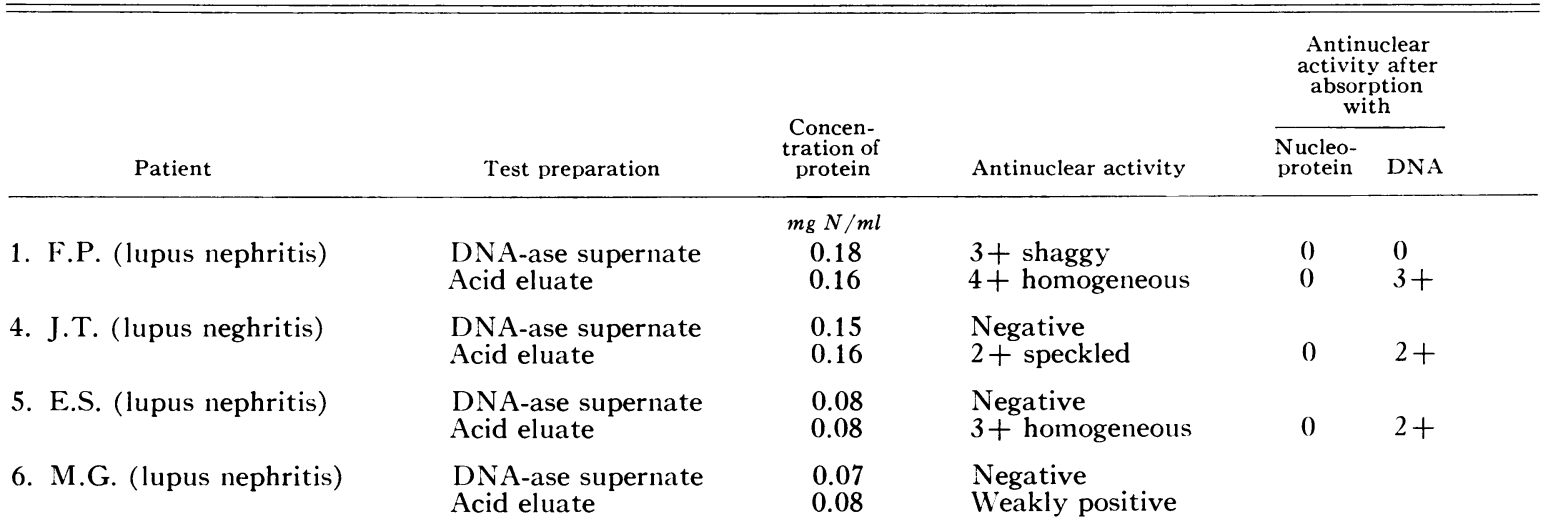




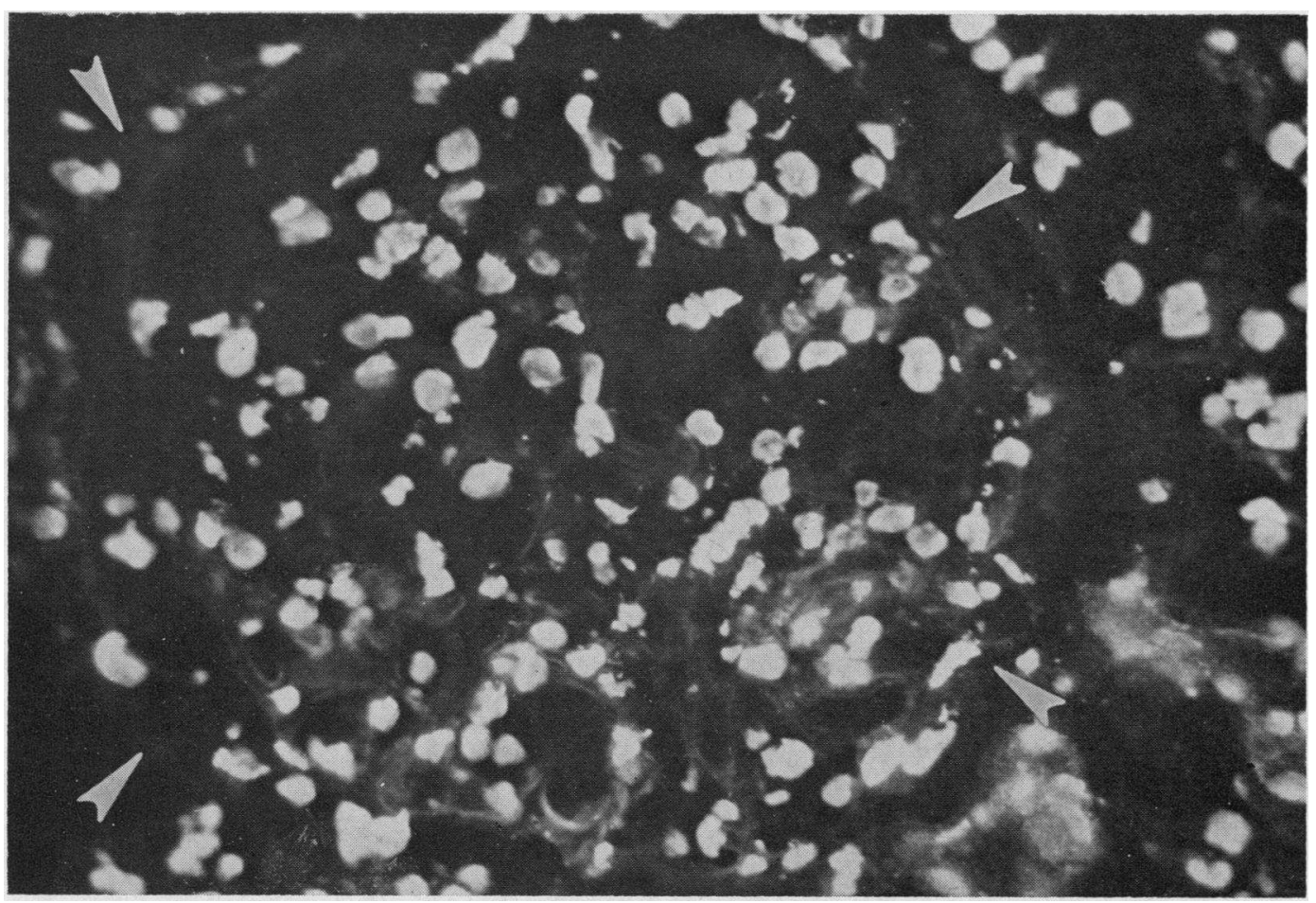

Fig. 2. Antinuclear reaction of acid eluate of disRupted DNA-ASe-treated glomeruli of Patient 1 (FP) ON A SECTION OF NORMAL HUMAN KIDNEY. Nuclear staining is homogeneous, and glomerular basement membrane or other tissue structures are not stained. The arrows define the capsule of a glomerular tuft. $(\times 312$.

reactive eluates. The patterns of nuclear fluorescence were generally homogeneous.

Results with acid eluates obtained after disruption of glomeruli and deoxyribonuclease treatment confirmed the above findings (Table V). Acid eluates at 0.08 to $0.18 \mathrm{mg}$ protein $\mathrm{N}$ per $\mathrm{ml}$ showed antinuclear activity that was strong and of a homogeneous pattern in Patients 1 and 5 (Figure 2). The eluate in Patient 4 gave a speckled reaction of moderate intensity. With Patient 6 , the antinuclear activity was weak. No staining of glomerular basement membrane or other tissue structures was found. Absorption of these eluates (Patients 1, 4, and 5) with calf thymus nucleoprotein before staining eliminated nuclear reactivity, whereas absorption with DNA diminished it slightly. Tests with the supernate obtained by DNA-ase digestion of disrupted glomeruli showed antinuclear activity in one instance (Patient 1 ). The nuclear staining related to $\gamma \mathrm{G}$-globulin was of a ragged or "shaggy" pattern (Figure 3 ). No other tissue structure was stained. Absorption of this DNA-ase digest with either nucleoprotein or DNA completely abolished its nuclear reactivity (Table V). Tests of glomerular eluates for reaction with DNA-coated bentonite particles were inconclusive due to the tendency of such eluates to induce nonspecific agglutination.

On immunoelectrophoretic analysis, acid eluates of isolated glomeruli from Patients 1 to 7 contained $\gamma \mathrm{G}$-globulin, whereas $\gamma \mathrm{A}-, \gamma \mathrm{M}-$, and $\beta_{1 \mathrm{C}^{-}}$ globulins were not detected (Figure 4). Neutral saline eluates revealed only negative or trace reactions for $\gamma \mathrm{G}$-globulin. None was detectable in the acid eluates from control Patients 11 and 12 .

\section{Discussion}

The procedure employed for elution of bound immunoglobulin from tissues was an adaptation of previously described methods of dissociating immune complexes at acid $\mathrm{pH}$ (12). Preliminary experiments that we carried out to determine optimal conditions for dissociating immune com- 


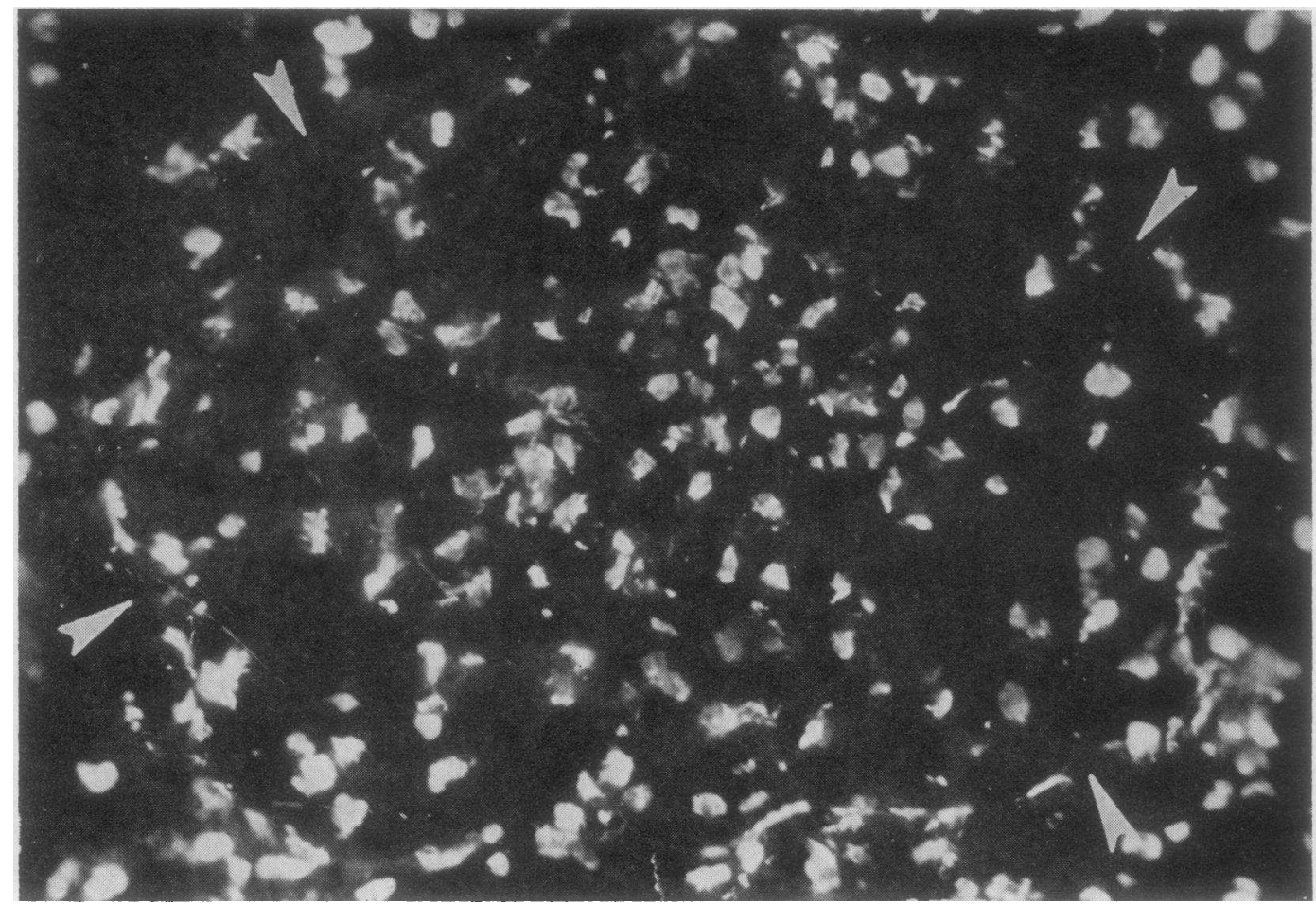

Fig. 3. Antinuclear reaction of DNA-ase digestion supernate of disrupted glomeruli of PaTIENT 1 (FP) ON A SECTION OF NORMAL HUMAN KIDNEY. The pattern of nuclear straining is more ragged or "shaggy," and non-nuclear structures are not stained. Arrows define capsule of a glomerulus. $(\times 312$.

plexes [bovine serum albumin (BSA)-anti-BSA] prepared at equivalence showed that a maximal yield of antibody was eluted from the immune precipitates at $\mathrm{pH} 3.0$ with constant shaking for 2 hours at room temperature. Furthermore, under these conditions acid washing of kidney sections in general resulted in marked reduction of staining of renal bound immunoglobulin, and the quantitative yields of eluted $\gamma$-globulin from cortex homogenates or isolated glomeruli were sufficient to demonstrate presence of associated serologic activity for nuclear antigens.

Bound immunoglobulin in kidneys was localized to multiple sites, including glomeruli, vessel walls, tubular casts, and occasionally tubular nuclei and tubular basement membrane. It was probable that eluates of cortex homogenates included $\gamma$-globulin derived from one or more of these loci, depending on the kidney specimens under study. Tubular protein casts might be considered a source of the eluted reactive globulin, inasmuch as $\gamma$-globulinuria is a common finding in lupus nephritis (13), and antinuclear activity has been demonstrated in concentrated urine specimens $(13,14)$. However, acid washing of kidney specimen sections performed in a manner similar to the elution procedure was found not to diminish the extent of fluorescent staining of $\gamma \mathrm{G}$-globulin in tubular casts, whereas in the same sections staining was markedly diminished or abolished in glomeruli. Diminution in staining of bound $\gamma$-globulin in tubular nuclei and tubular basement membrane was also obtained. These observations are similar to those in other reports $(2,3)$.

The results obtained with isolated glomerular preparations clearly associated the eluted $\gamma$-globulin with these structures. In these preparations more than $90 \%$ of the tissue elements were glomeruli; the remainder included tubular cells and rarely fibrous tissue elements, whereas casts were rarely seen. The repeated washing procedures required for isolation and purification of glomeruli excluded serum contamination.

The properties of the reactive eluates from both 
homogenates and glomeruli differed from those reported by Freedman and Markowitz (4). Demonstration of antinuclear activity was not dependent on presence of fresh normal human serum. The reported requirement for a complement-like factor could conceivably be related to quantitative factors, to the specificity of the antiserum employed in the immunofluorescent technique, or, as claimed, to properties of the eluted antinuclear antibody. The present work did not substantiate the latter possibility.

Acid eluates of glomeruli of the seven kidneys with glomerular bound immunoglobulins revealed only $\gamma \mathrm{G}$-globulin, although $\gamma \mathrm{A}$-globulin, $\gamma \mathrm{M}$-globulin, or both, were demonstrated in glomeruli of three patients. The intensity of the staining reaction for these latter two immunoglobulins was graded only $1+$ in cases where they were present. It is probable that failure to detect these immunoglobulins in the acid eluates was related to low quantitative yield. No evidence of $\beta_{1 \mathrm{C}} / \mathrm{B}_{1 \mathrm{~A}}$-globulin was found in eluates of either cortex homogenates or glomeruli in any of the patients that showed deposits of this complement component.

Disruption of glomeruli followed by deoxyribonuclease treatment before acid elution increased the total yield of protein and intensity of antinuclear activity in eluates obtained from lupus nephritis kidneys. Absorption with calf thymus nucleoprotein abolished nuclear reactivity in three of these eluates. Absorption with DNA diminished the staining intensity without abolishing it. The $\gamma \mathrm{G}$-globulin in one of the deoxyribonuclease digests (Patient 1 ) revealed antinuclear activity, whose specificity was related to DNA, as evidenced by a shaggy pattern and complete elimination of staining by absorption with DNA. Eluates of isolated glomeruli from Patients 1 and 5 exhibited a homogeneous pattern of reaction with nuclei consistent with that observed with antinucleoprotein antibodies (15). The glomerular eluates of Patient 4 showed a speckled pattern of staining, suggestive of reaction with other nuclear constituents, such as the nonhistone acidic moiety in buffer extracts of nuclei to which this pattern has been related $(15,16)$.

The kidneys of one lupus nephritis patient and two nonlupus patients showed lesser deposits of renal bound immunoglobulins, and their sera had

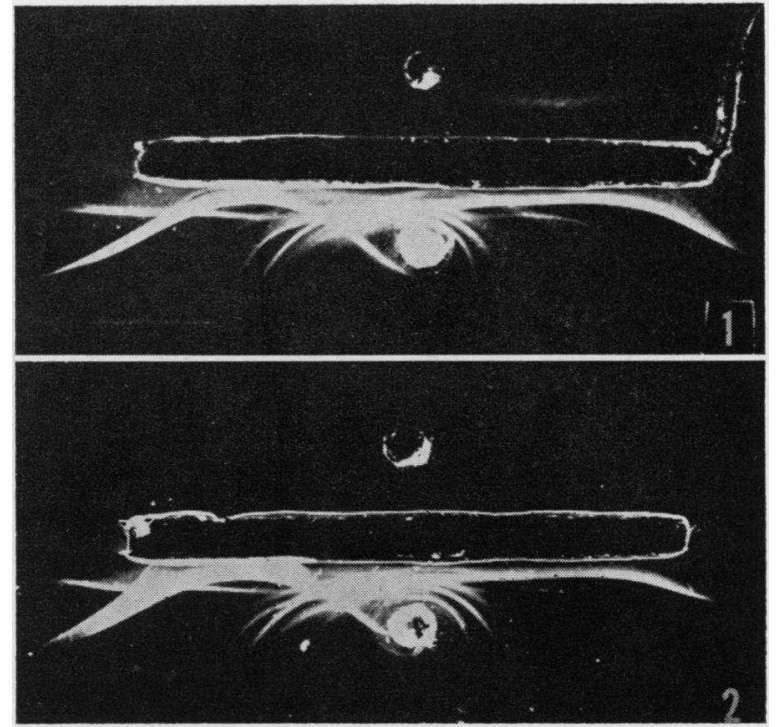

Fig. 4. IMmUNOELECTROPHORETIC ANALYSIS OF ACID AND NeUtral eluates of ISOlated glomeruli. Cathode is at right. The central trough in each case contained rabbit antiserum to whole human serum. Acid eluate from isolated glomeruli of Patient 1 (FP) is in upper well in slide 1 , and neutral eluate is in upper well in slide 2 . Lower well in each slide contained serum of patient FP. A prominent $\gamma \mathrm{G}$-globulin arc is demonstrated with the acid eluate.

low antinuclear titers and no detectable anti-DNA antibodies. Acid eluates from these kidneys were nonreactive with nuclei. Correlative observations suggest, although the patients studied are few, that the presence of antinuclear activity in glomerular eluates from five lupus nephritis kidneys was associated with intensely stained deposits of immunoglobulins in glomeruli, with elevated titers of serum antinuclear factors, and with anti-DNA antibodies in the serum in three of the five patients.

Although a correlation of elevated serum antinuclear and anti-DNA titers with renal disease has been reported in $\operatorname{SLE}(17,18)$, it has not been proven that this correlation indicates a direct pathogenetic role for such antibodies. In two of the six patients reported in this work, bound $\gamma$-globulin was observed in tubular nuclei, indicating that in certain individuals, the renal tubular cells may be permeable to antinuclear factors. This observation is similar to that reported by Paronetto and Koffler (3) and is analogous to the findings reported by Tan and Kunkel (19) 
in the case of dermal nuclei in skin lesions of patients with SLE. However, it should be emphasized that nuclear deposits of $\gamma$-globulin in renal biopsies have been observed only rarely in this laboratory and such findings appear unrelated to the underlying glomerular pathology. Rather, the demonstration of antinuclear activity in glomerular eluates provides support for a pathogenetic role of immune complexes containing antinuclear factors that have become deposited in glomeruli. This view is in accordance with the proven pathologic effects of circulating complexes on the kidney in experimental serum sickness nephritis (20) and of injection of such complexes in animals (21). In SLE, circulating complexes may be derived from immune response and subsequent reaction with soluble antigens of tissues presumably released into the circulation as a result of inflammation, injury, or unknown metabolic processes. It is relevant $(22,23)$ that an elevated level of serum DNA has been found in SLE and increased DNA turnover has been demonstrated as indicated by increased numbers of DNA-synthesizing cells in peripheral blood (24). The soluble antigens derived from nuclei against which antibodies have been observed in sera of SLE patients include DNA, histone, buffer extract components, and soluble forms of DNAprotein $(25-27)$. It is not unlikely that in the course of tissue injury or destruction, in association with release of lysosomal enzymes (28), fragmentation and breakdown of insoluble nucleoproteins and of DNA may result. It has been claimed that Feulgen-positive material may occasionally be demonstrated in glomerular basement membranes in lupus nephritis $(29,30)$.

\section{References}

1. Krishnan, C., and M. H. Kaplan. Antinuclear activity in acid eluates of glomeruli from lupus nephritis kidneys. Fed. Proc. 1966, 25, 309.

2. Freedman, P., J. H. Peters, and R. M. Kark. Localization of gamma-globulin in the diseased kidney. Arch. intern. Med. 1960, 105, 524.

3. Paronetto, F., and D. Koffler. Immunofluorescent localization of immunoglobulins, complement, and fibrinogen in human diseases. I. Systemic lupus erythematosus. J. clin. Invest. 1965, 44, 1657.

4. Freedman, P., and A. S. Markowitz. Isolation of antibody-like gamma-globulin from lupus glomeruli. Brit. med. J. 1962, 1, 1175.
5. Svec, K. H., J. D. Blair, and M. H. Kaplan. Immunopathologic studies in systemic lupus erythematosus (SLE). I. Tissue-bound immunoglobulins in relation to serum antinuclear immunoglobulins in systemic lupus and in chronic liver disease with LE cell factor. J. clin. Invest. 1967, 46, 558.

6. Kunkel, H. G., and A. Tiselius. Electrophoresis of proteins on filter paper. J. gen. Physiol. 1951, 35, 89.

7. Greenspon, S. A., and C. A. Krakower. Direct evidence for the antigenicity of the glomeruli in the production of nephrotoxic serums. Arch. Path. 1950, 49, 291.

8. Scheidegger, J. J. Une micro-méthode de l'immunoélectrophorèse. Int. Arch. Allergy 1955, 7, 103.

9. Svec, K. H., and M. H. Kaplan. A variant L. E. cell factor reactive only with "altered" nuclear material. Arthr. and Rheum. 1963, 6, 11.

10. Chargaff, E. Isolation and composition of desoxypentose nucleic acids and of the corresponding nuc'eoproteins in The Nucleic Acids, E. Chargaff and J. N. Davidson, Eds. New York, Academic Press, 1955, vol. 1, p. 313.

11. Bozicevi h, J., J. P. Nasou, and D. E. Kayhoe. Desoxyribonucleic acid (DNA)-bentonite flocculation test for lupus erythematosus. Proc. Soc. exp. Biol. (N. Y.) 1960, 103, 636.

12. Campbell, D. H., and F. Lanni. The chemistry of antibodies in Amino Acids and Proteins, M. Greenberg, Ed. Springfield, Ill, Charles C Thomas, 1951, p. 673.

13. Stevens, M. B., and B. Knowles. Significance of urinary gamma globulin in lupus nephritis. 1. Electrophoretic analysis. New Engl. J. Med. 1962, 267, 1159.

14. Hanson, L. A., and E. M. Tan. Characterization of antibodies in human urine. J. clin. Invest. 1965, 44, 703.

15. Beck, J. S. Variations in the morphological patterns of "autoimmune" nuclear fluorescence. Lancet 1961, 1, 1203.

16. Lachmann, P. J., and H. G. Kunkel. Correlation of antinuclear antibodies and nuclear staining patterns. Lancet 1961, 2, 436.

17. Townes, A. S., C. R. Steward, Jr., and A. G. Osler. Immunologic studies of systemic lupus erythematosus. II. Variations of nucleoprotein-reactive gamma globulin and hemolytic serum complement levels with disease activity. Bull. Johns Hopk. Hosp. 1963, 112, 202.

18. Seligmann, M. DNA antibodies. Arthr. and Rheum. 1963, 6, 542.

19. Tan, E. M., and H. G. Kunkel. An immunofluorescent study of the skin lesions in systemic lupus erythematosus. Arthr. and Rheum. 1966, 9, 37.

20. Dixon, F. J., J. D. Feldman, and J. J. Vazquez. Ex. perimental glomerulonephritis. The pathogenesis of a laboratory model resembling the spectrum of 
human glomerulonephritis. J. exp. Med. 1961, 113, 899.

21. McCluskey, R. T., B. Benacerraf, J. L. Potter, and F. Miller. The pathologic effects of intravenously administered soluble antigen-antibody complexes. I. Passive serum sickness in mice. J. exp. Med. 1960, 111, 181.

22. Tan, E. M., P. H. Schur, R. I. Carr, and H. G. Kunkel. Deoxyribonucleic acid (DNA) and antibodies to DNA in the serum of patients with systemic lupus erythematosus. J. clin. Invest. 1966, 45, 1732.

23. Barnett, E. V. Detection of nuclear antigens (DNA) in normal and pathologic human fluids by quantitative complement fixation. Arthr. and Rheum. 1966, 9, 488.

24. Cooper, I. A., and B. G. Firkin. Deoxyribonucleic acid synthesizing cells in the peripheral blood of patients with "auto-immune" disorders. Aust. Ann. Med. 1965, 14, 142.

25. Holman, H. R., H. R. G. Deicher, and H. G. Kunkel.
The L. E. cell and L. E. serum factors. Bull. N. Y. Acad. Med. 1959, 35, 409.

26. Tan, E. M., and H. G. Kunkel. Characteristics of a soluble nuclear antigen precipitating with sera of patients with systemic lupus erythematosus. J. Immunol. 1966, 96, 464.

27. Tan, E. M. Precipitating antibody in systemic lupus erythematosus to a soluble DNA-protein antigen. Arthr. and Rheum. 1966, 9, 547.

28. Weissman, G., and L. Thomas. Steroids, lysosomes, and systemic lupus erythematosus. Bull. N. Y. Acad. Med. 1962, 38, 779.

29. Gueft, B., and A. Laufer. Further cytochemical studies in systemic lupus erythematosus. Arch. Path. 1954, 57, 201.

30. Browne, J. T., M. P. Hutt, J. F. Reger, and S. W. Smith. Localization of "fibrinoid" deposit in lupus nephritis. An electron microscopic demonstration of glomerular endothelial cell phagocytosis. Arthr. and Rheum. 1963, 6, 599. 